\title{
Endring i forekomst av villet egenskade hos ungdom
}

\author{
Av Anita. I. Tørmoen, Martin Ø. Myhre, Fredrik A. Walby, Berit Grøholt \\ og Ingeborg M. Rossow
}

Denne artikkelen er basert på Tørmoen et al. (2020)

\section{SAMMENDRAG}

Selvskade er vanlig hos ungdommer, og er assosiert med psykiske helseproblemer og negative livshendelser. Denne artikkelen beskriver resultatene fra en ny studie om endringer i forekomsten av selvskade blant ungdomsskoleelever i Norge og diskuterer implikasjoner av funnene. To kryss-seksjonelle undersøkelser blant ungdommer $\mathrm{i}$ ungdomsskolen (8.-10. klasse) ble benyttet for å analysere endring i forekomsten av selvskade: Ung i Norge-undersøkelsen fra 2002 ( $N=5842$ ) og Ungdata-undersøkelsen fra 2017 og 2018 ( $N=29$ 063). Fra undersøkelsene hentet vi forekomst av selvskade siste år og kjente risikofaktorer for selvskade hos ungdom. Vi analyserte endring i forekomst av selvskade blant ungdomsskoleelever fra 2002 til 2017/2018, og undersøkte i hvilken grad den observerte endringen kunne forklares av samtidig endring $i$ underliggende risikofaktorer. Forekomsten av selvskade siste år økte fra 4,1 \% i 2002 til 16,2 \% i 2017/2018. Blant risikofaktorene økte forekomsten av depressive symptomer, mens forekomsten av antisosial atferd, eksponering for vold og alkoholberuselse sank. Økningen av depressive symptomer forklarte en liten del av økningen i selvskade, men hadde liten betydning når alle risikofaktorer ble tatt $\mathrm{i}$ betraktning. Vi fant at forekomsten av selvskade siste år hos ungdom firedoblet seg i løpet av 15 år. Etablerte risikofaktorer forklarer ikke hele den observerte økningen. Det er behov for mer forskning for å forstå det komplekse samspillet mellom faktorer som kan påvirke forekomsten av selvskade hos ungdom.

\section{ABSTRACT}

Self-harm is prevalent among adolescents and associated with mental health problems and negative life-events. A recent published study found a steep increase in prevalence of self-harm among adolescents in Norway. This paper aims to disseminate the results and discuss implications. Two crosssectional school-based surveys among adolescents (grades $8-10)$ in Norway were conducted in $2002(N=5842)$ and in $2017 / 18(N=29063)$. Past year prevalence of self-harm and variables on risk factors was analyzed to examine whether change had occurred. Further, we analyzed to what extent changes in self-harm correlates could explain the observed periodical change in prevalence of self-harm. An increase from $4.1 \%$ to $16.2 \%$ in self-harm prevalence was observed from 2002 to $2017 / 18$. Among the assessed risk factors for self-harm, depressive symptoms increased, while anti-social behavior, exposure to violent acts and drinking to intoxication decreased. The increase in depressive symptoms contributed to explain a small amount of the increase in self-harm but was outweighed when all other associated factors were included. Self-harm prevalence increased 4-fold among Norwegian adolescents over a 15-year period. The factors at hand could not explain the observed increase. Further research is needed to understand the complex interplay between factors that might operate. 
tivene «|a» eller «Nei», og vi sammenliknet andelen som svarte «|a, for mindre enn ett år siden» på spørsmålet i UiN 2002 med andelen som svarte «|a» på spørsmålet $\mathrm{i}$ UngData i 2017 og 2018. Videre ble følgende risikofaktorer for selvskading som var identiske eller svært like mellom UiN og Ungdata inkludert i analysene: depressive symptomer, antisosial atferd, alkoholberuselse, det å ha en kjæreste, familieøkonomi, og eksponering for voldelige trusler eller handlinger.

Andelen ungdomsskoleelever som rapporterte selvskading siste år, økte for begge kjønn, på alle klassetrinn, og både i urbane og rurale strøk. Fra 2002 til 2017/2018 okte andelen fra $4.1 \%$ til $16.2 \%$. Som figur 1 viser, var økningen i selvskading betydelig mer uttalt hos jenter enn hos gutter. Blant jentene fant vi en forekomst av villet egenskade på 22.4 \% i 2017/18.

I samme periode var det en okning i depressive symptomer, og særlig hos jenter, som kunne forklare en del av økningen i selvskading. Andre viktige risikofaktorer som voldseksponering, alkoholberuselse, og antisosial atferd ble imidlertid mindre vanlig i løpet av den samme perioden, og kan dermed ikke bidra til å forklare økningen.

Vår studie (Tørmoen et al., 2020) fant en betydelig økning i forekomsten av selvskading hos ungdomsskoleelever over en 15 års periode fra 2002 til 2017 og 2018. En samtidig okning i forekomst av depressive symptomer forklarte bare delvis økningen. Med andre ord, det har skjedd en dramatisk okning i forekomst av selvskading blant ungdom, som vi i liten grad kan forklare med de tilgiengelige variablene i denne studien.

\section{Hva betyr endringen i forekomst av selvskading?}

En dramatisk okning i forekomsten av villet egenskade er alvorlig av flere grunner, uansett om enkelte av hendelsene kan være av mindre farlig karakter. Villet egenskade er forbundet med personlig lidelse, og betydelig $₫ \mathrm{kt}$ risiko for senere psykiske vansker. Tidligere er det funnet en klar korrelasion mellom forekomst i villet egenskade og selvmord (Rodway et al., 2016). Den observerte okningen tilsier at utviklingen i selvmordsrater hos ungdom bør overvåkes nøye for å se om økningen i villet egenskade finnes igjen i selvmordsratene for unge. Samtidig vet vi at når villet egenskade rapporteres i spørreundersøkelser, som den foreliggende studien er basert på, kan det også omfatte episoder med ufarlig egenskade. Vi vet ikke hvor stor andel av disse selvrapporterte episodene som er behandlingstrengende. Det kan også tenkes at noe av okningen kan forklares med at rapporteringsvilligheten har endret seg i samme tidsperiode. Det har vært et generelt større fokus på mental helse og åpenhet rundt selvskading. Ungdoms forhold til å dele informasjon om vanskelige tema kan ha endret seg for eksempel som følge av økt bruk av internett og sosiale medier, og dette kan ha påvirket hvordan man svarer på spørsmål om slike temaer i spørreundersøkelser. Således kan

Figur 1. Endring i forekomst av selvskading fra 2002 til 2017/18 for alle på ungdomstrinnet, for gutter og jenter, for hvert klassetrinn og for de som bor i urbane eller rurale strøk.
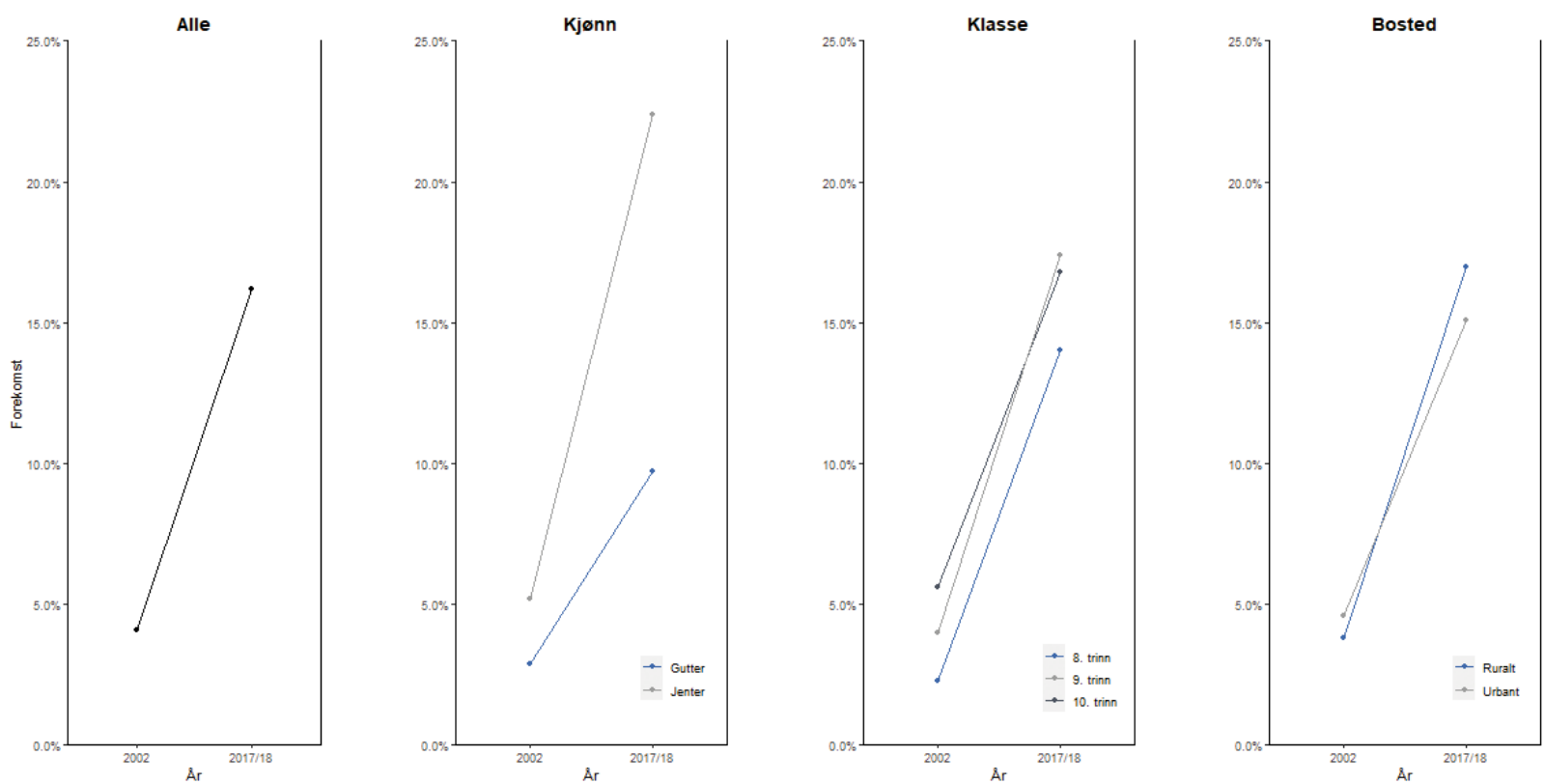
det være flere medvirkende årsaker til den observerte endringen, som ikke nødvendigvis er så dramatisk som tallene kan gi uttrykk for.

Uansett vil vi hevde det er meget viktig å monitorere selvskading blant ungdom nøye. Vi trenger mer kunnskap for bedre å skille ulike typer villet egenskadeatferd. Blant de $16 \%$ vi har beskrevet, vil det åpenbart være behov for differensierte tiltak, og tiltak bør settes inn på flere nivåer. Både universelle virkemidler rettet mot ungdom generelt, og selektive virkemidler som kan nå grupper av særlig sårbare ungdommer spesielt, er aktuelle. Eksempelvis kan undervisning som øker ungdoms kunnskap om mental helse være aktuelt, men også tiltak som kan senke terskelen for å be om hielp samt å giøre kunnskapsbasert behandling mer tilgiengelig. Vi trenger å forstå bedre hvorfor omfanget av villet egenskade har økt betydelig. Vi vet at samfunnet og oppvekstvilkår for unge mennesker har endret seg dramatisk de siste tjue årene. Herunder er det en ny virkelighet knyttet til sosialt nettverk på virtuelle plattformer der deling av tidligere mer private tanker, følelser og hendelser er svært vanlig, på godt og vondt. Dette er vi allerede i gang med å se nærmere på i nye forskningsprosjekter.

\section{REFERANSER}

Collishaw, S. (2015). Annual Research Review: Secular trends in child and adolescent mental health. Journal of Child Psychology and Psychiatry, 56(3), 370-393. doi:10.1111/icpp.12372

Fleming, T. M., Clark, T., Denny, S., Bullen, P., Crengle, S., Peiris-Iohn, R., .. Lucassen, M. (2014). Stability and change in the mental health of New Zealand secondary school students 2007-2012: Results from the national adolescent health surveys. 48(5), 472-480. doi:10.1177/0o04867413514489

Geulayov, G., Casey, D., McDonald, K. C., Foster, P., Pritchard, K., Wells, C., ... Hawton, K. (2018). Incidence of suicide, hospital-presenting non-fatal self-harm, and community-occurring non-fatal self-harm in adolescents in England (the iceberg model of self-harm): a retrospective study. The Lancet Psychiatry, 5(2), 167-174. doi:10.1016/S2215-0366(17)30478-9

Geulayov, G., Kapur, N., Turnbull, P., Clements, C., Waters, K., Ness, I., ... Hawton, K. (2016). Epidemiology and trends in non-fatal self-harm in three centres in England, 2000-2012: findings from the Multicentre Study of Self-harm in England. BMI Open, 6(4), e010538. doi:10.1136/ bmiopen-2015-010538

Gillies, D., Christou, M. A., Dixon, A. C., Featherston, O. I., Rapti, I., GarciaAnguita, A..... Christou, P. A. (2018). Prevalence and Characteristics of Self-Harm in Adolescents: Meta-Analyses of Community-Based Studies 1990-2015. Journal of the American Academy of Child and Adolescent Psychiatry, 57(10), 733-741. doi:10.1016/i.jaac.2018.06.018

Hawton, K., Bergen, H., Kapur, N., Cooper, I., Steeg, S., Ness, I., \& Waters, K. (2012). Repetition of self-harm and suicide following self-harm in children and adolescents: findings from the Multicentre Study of Self-harm in England. Journal of Child Psychology and Psychiatry, 53(12), 1212-1219. doi:10.1111/j.1469-7610.2012.02559.x

Pape, H., Rossow, I., \& Brunborg, G. S. (2018). Adolescents drink less: How, who and why? A review of the recent research literature. Drug and Alcohol Review, 37(S1), S98-S114. doi:10.1111/dar.12695

Rodway, C., Tham, S. G., Ibrahim, S., Turnbull, P., Windfuhr, K., Shaw, I., .. Appleby, L. (2016). Suicide in children and young people in England: A consecutive case series. The Lancet Psychiatry, 3(8), 751-759. doi:10.1016/ s2215-0366(16)30094-3
Rossow, I., \& Wichstrøm, L. (2010). Receipt of Help After Deliberate SelfHarm Among Adolescents: Changes Over an Eight-Year Period. Psychiatric Services, 61(8), 783-787. doi:10.1176/ps.2010.61.8.783

Twenge, I. M., Joiner, T. E., Rogers, M. L., \& Martin, G. N. (2018). Increases in Depressive Symptoms, Suicide-Related Outcomes, and Suicide Rates Among U.S. Adolescents After 2010 and Links to Increased New Media Screen Time. Clinical Psychological Science, 6(1), 3-17. doi:10.1177/2167702617723376

Tormoen, A. I., Myhre, M., Walby, F. A., Groholt, B., \& Rossow, I. (2020). Change in prevalence of self-harm from 2002 to 2018 among Norwegian adolescents. European Journal of Public Health. doi:10.1093/eurpub/ckaao42

Tormoen, A. I., Rossow, I., Larsson, B., \& Mehlum, L. (2013). Nonsuicidal self-harm and suicide attempts in adolescents: differences in kind or in degree? Social Psychiatry and Psychiatric Epidemiology, 48(9), 1447-1455. doi:10.1007/s00127-012-0646-y

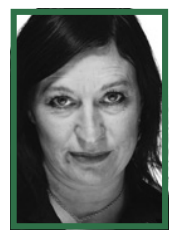

\section{ANITA JOHANNA TØRMOEN er}

ph.d., førsteamanuensis og leder av utdanningsvirksomheten ved Nasjonalt senter for selvmordsforskning og -forebygging, Institutt for klinisk medisin, Universitetet i Oslo.

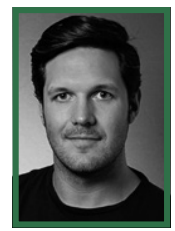

MARTIN Ø. MYHRE er vernepleier med en mastergrad i atferdsvitenskap, og stipendiat ved NSSF på prosjektet «Selvmord i rusbehandling». Han er også prosjektmedarbeider ved Nasjonalt kartleggingssystem for selvmord, og har lang erfaring fra akuttpsykiatri og tverrfaglig spesialisert rusbehandling.

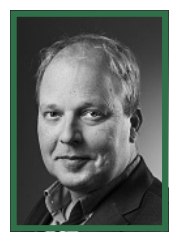

FREDRIK A. WALBY er forsker, psykologspesialist ved Nasjonalt senter for selvmordsforskning og -forebygging, Institutt for klinisk medisin, Universitetet i Oslo.

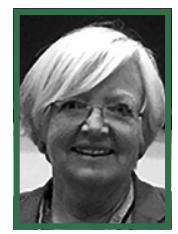

BERIT GRØHOLT, barnepsykiater og professor emeritus, har gjennom mangeårige kliniske og forskningsmessige bidrag om ungdom, selvmord, selvmordsforsøk og selvskading vært sentral i å frembringe kunnskap. Hun har redigert flere bøker og publisert en rekke artikler. Grøholt er pensjonist, men bidrar fremdeles til fagfeltet på ulike måter.

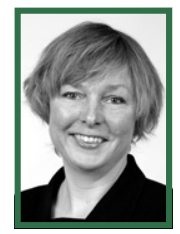

INGEBORG M. ROSSOW er seniorforsker ved FHI og har arbeidet med rusforskning i over 30 år. Rossow har publisert mange artikler om rus, selvskading og selvmordsatferd, samt epidemiologiske studier av ungdoms levekår og utfordringer. Rossow har også skrevet en rekke bøker og bokkapitler og bidratt til offentlige utredninger og politiske høringsprosesser på sitt fagfelt. 